\title{
Elementary School of Ecosystem-Based \\ (Study on the Implementation of Education Policies in Elementary School of Ecosystem-Based Management State of Indonesia)
}

\author{
Johan Yunus, M. Tauchid Noor \& Kridawati Sadhana
}

University of Merdeka Malang

Indonesia

\begin{abstract}
In essence, National education functions to develop and shape the character and civilization of a nation with dignity in the framework of educating the nation's life, aiming at developing the potential of students to become human beings who believe and fear God Almighty, have a noble character, are healthy, knowledgeable, capable, creative, independent, and become a democratic and responsible citizen "(Law No. 20 of 2003 on the National Education System article 3). Then, in article 4 of the National Education System Law, Number 20 of 2003 states that "Education is held by empowering all components of society through participation in the implementation and control of the quality of education services". This study examines the implementation of ecosystem-based education in SDN 16, Rukoh, Banda Aceh because basic education is the main pillar of cultivating the character of the nation's children. Especially in the context of Aceh as the Veranda of Mecca which underlies all of its policies with Islamic principles. Thus, the title of this dissertation proposal is Ecosystem-Based Elementary School (Study on Implementation of Curriculum 2013 on Ecosystem-Based Education in SD Negeri 16 Banda Aceh City). The purpose of this study was to describe and analyze the implementation of the education office's policies on ecosystem-based schools at SD Negeri 16 Banda Aceh. Describe and analyze the supporting and inhibiting elements of the implementation of ecosystem-based school education policies at SD Negeri 16 Banda Aceh. In the research discussion, the main theory is used, namely the theory of educational policy implementation and several supporting theories, namely the theory of education, the sociological theory of education, the concept of the learning process, and the concept of the educational ecosystem. This research method using a qualitative descriptive approach with data analysis used interactive analysis. The results of research on the implementation of ecosystem-based primary school education policies can be formulated through findings and propositions. As the final result, the major proposition is as follows: The learning process through the implementation of ecosystem-based elementary school education is formed through the involvement and support of school stakeholders and the presence of local government so that personality, character, environmental awareness are created.
\end{abstract}

Keywords: Education Policies, National Education, Primary Schools, Ecosystems.

\section{INTRODUCTION}

In essence, National education functions to develop and shape the character and civilization of a nation with dignity in the framework of educating the nation's life, aiming at developing the potential of students to become human beings who believe and fear God Almighty, have noble character, are healthy, knowledgeable, capable, creative, independent, and become a democratic and responsible citizen "(Law No. 20 of 2003 on the National Education System article 3). Then, in article 4 of the National Education System Law Number 20 of 2003 states that "Education is held by empowering all components of society through participation in the implementation and control of the quality of education services".

In the era of globalization and modernization with various scientific and technological advances that are very fast, creative and educational steps are needed for elementary school children as the nation's next generation. Positive activities are needed to build the character of the younger generation who have empathy and high concern for the environment around them. The student learning process must be fun, so that students are comfortable carrying out learning activities. In addition to interactions between fellow humans, the natural environment can also be friends and teachers who are symbiotic with each other and teach the values of life that are very qualified. We can learn from the sun, moon, stars, water, soil, air, animals, plants and others. For example, let's look at the sun. The sun always rises from the east and sets in the west. The sun stores a lot of energy for human life but the sun is also axiomatic; orderly and disciplined.The development of globalization in which the people of Aceh are an inseparable part of it, the issue of education is one of the main pillars that need to be nurtured and developed. Philosophically, Socrates 
affirms that education is a process of human development towards wisdom, knowledge and conduct. Therefore, building cognition, affection and psychomotor aspects in a balanced and sustainable manner is the highest educational value.

The research objective was to describe and analyze the implementation of the education office's policies on ecosystem-based schools at State 16 Elementary School of Banda Aceh and to describe and analyze the supporting and inhibiting elements of the implementation of ecosystem-based school education policies at State 16 Elementary School of Banda Aceh.

\section{STUDY REFERENCES}

\subsection{Public Policy Theory}

Basically, the functions of the Government of a State include the functions of allocation, distribution, and stabilization. The existence of these functions is to maintain and guarantee the integrity and survival of the State, to create an equitable distribution of development results, and to realize community welfare in an aggregate manner. One of the policies referred to is public policy, namely policies formulated and developed by the government in regulating the life of the State or It can also be interpreted as the direction or action taken by the government to overcome a problem in the State, such as the provision of quality human resources in facing the era of globalization and the demands of increasingly basic and complex public service needs, however, according to Christoper Pollit (1979: 23) states every discussion or thought and analysis of Public Policy must always be centered on the Balance Of Three Central Principles, namely between formulation, implementation, and evaluation [1].

\subsection{Public Policy Implementation Theory}

Etymologically, the word implementation is a translation of the English word Implementation, which comes from the verb to implement. So implementation means an activity related to the completion of a job in the use of means (tools) to obtain results. According to Sadhana (2011: 172) Policy implementation can be defined as "As an activity to settle or implement a public policy that has been approved by the use of means (tools) to achieve policy objectives"[2].

\subsection{Educational Theory}

Education is a human effort to foster his personality according to the values in society and culture. To study this, there are four theories of human development that can explain it, namely:

a) Empiricism Theory

This theory states that children born into the world are like blank paper or wax-covered tables that have no writing on them. This means that child development depends on experiences during his life. The figure of this theory is John Locke, a philosopher from England.

b) Theory of Nativism

This theory states that human development is determined by the traits the child has from birth. This means that the environment has no effect on children's education and development, because the results of education are entirely dependent on the child's own nature. The figure of this theory is Schopenhuer, a philosopher from Germany.

c) Naturalism Theory

This theory implies that all children who are good when they come from the hand of the Creator, but all become corrupted in the hands of humans. The figure of this theory is JJ Rousseau, a philosopher from France.

d) Convergence Theory

This theory is a combination of two opposing theories, namely the theory of empiricism and the theory of nativism. This theory states that children are brought into the world with good and bad traits. This means that children's development will be determined by their nature and environment. The figure of this theory is William Stern, an education expert from Germany.

\subsection{Theory Sociology of Education}

Sociology as a science which has a field of inquiry, viewpoints, methods and structures of knowledge. The object of research is human behavior in groups, the point of view is to see the nature of cultural society and while the composition of knowledge in sociology contains concepts and principles regarding the life of social groups, their culture, the development of personality building through the roles played in group life. On the other hand, educational sociology is a branch of science (from the psychology of education) which discusses the social interaction process of children from family, school to adulthood as well as with the socio-cultural conditions that exist in society and the state. 


\subsection{Concept of Learning Process}

In general, education is an anthropological phenomenon whose age is almost as old as human history itself. Referring to the opinion of Niccolo Machiavelli as quoted by (Koesoema, 2010: 52) understanding education in terms of the continuous process of human self-improvement [3]. This happens because by nature humans have flaws and incompleteness. For him, human intervention through education is one way for humans to complement what is lacking from their nature, education can complement the imperfections in our natural nature. John Dewey in his writing (Siswoyo et al, 2007: 19) explains that education is a reconstruction or reorganization of experiences that add meaning to experiences, and which increase the ability to direct subsequent experiences [4]. Furthermore Siswoyo et al (2007: 19) defines that in a technical sense, education is a process by which society, through educational institutions (schools, colleges or through other institutions), deliberately transforms its cultural heritage, namely knowledge, values generation after generation of values and skills [4].

\subsection{Ecosystem-based Education Concept}

The 2013 curriculum is an integrated curriculum, namely a curriculum that integrates Skills, Themes, Concepts, and Topics both in the form of Within Sigle disciplines, Acrous several disciplines and Within and Acrous Learners. In other words, the 2013 curriculum is an integrated curriculum, namely a system or approach. learning that involves several scientific disciplines to provide meaningful and broad experiences to students. It is said to be meaningful because in an integrated curriculum, students will understand the concepts that students will learn is intact and realistic. It is said broadly because what students will get is not only within the scope of discipline but all across disciplines because they are viewed as related to one another.

\subsection{School Concept}

School is a social interaction system of an entire organization consisting of personal interactions linked together in an organic relationship (Wayne in Atmodiwiro book, 2000: 37) [5]. Meanwhile, based on law No.2 of 1989, schools are educational units that are tiered and continuous to carry out teaching and learning activities. According to Daryanto (1997: 544), schools are buildings or institutions for learning as well as places to receive and give lessons [6]. So, school as a social system is limited by a set of elements of activities that interact and form a school social unit which is thus actively creative, meaning that schools can produce something that is beneficial to society, in this case, educated people. From this definition, the school is an institution or organization that is authorized to carry out learning activities. As a school organization has certain requirements.

\subsection{Concept Ecosystem Based School}

The Ministry of Education and Culture (Kemendikbud) wants to make schools an educational ecosystem. This commented on the government's efforts to implement strengthening character education (PPK) in the five-day school policy (LHS). "The implementation uses three principles. It is in the National Education System Law, one of which is school-based education management, "said Minister of Education and Culture (Mendikbud) Muhadjir Effendy at the Ministry of Education and Culture Office, Senayan, Jakarta, Wednesday (12/7). According to Muhadjir, the education ecosystem was designed by Ki Hadjar Dewantara or what is known as the tri center of education, namely schools, community and family environment. He said that so far the three components have worked independently in educating children.

\section{METHOD RESEARCH}

\subsection{Research Approach}

This research uses a qualitative approach (Qualitative Research) because the researcher intends to obtain an in-depth picture of Ecosystem-Based Primary Schools (Study on the Implementation of the 2013 Curriculum on Ecosystem-Based Education in State 16 Elementary School of Banda Aceh City) is an in-depth and comprehensive research, because the indicators and research focus are not only on the curriculum, teachers and efforts to improve quality of education but also examines the factors that affect education in schools both internal and external factors.

\subsection{Research sites}

This research was conducted at Ecosystem-Based Elementary School in State 16 Elementary School of Banda Aceh City. The reason for choosing the location was that the location was easy to reach, elementary school was the first formal educational institution for children to recognize values, and the researcher's field of duty: researchers wanted to study carefully and obtain information and data related to the duties and responsibilities of the school in implementing the 2013 Curriculum.

\subsection{Focus Research}

Implementation of ecosystem-based education policies at State 16 Elementary School of Banda Aceh:

a) Preparation for the implementation of ecosystem-based school policies, 
b) Learning process,

c) Budget Support,

d) HR Quality Support,

e) Policy implementation strategy.

Supporting and inhibiting elements of the implementation of ecosystem-based learning at State 16 Elementary School of Banda Aceh:
a) Internally,
b) Externally.

\subsection{Technique Data collection}
a) Observation,
b) Interview,
c) Documentation

\subsection{Data Analysis Techniques}

Data analysis is also called data processing and interpretation. After collecting field data, both primary and secondary data are classified according to the topics discussed and analyzed descriptively (descriptive analysis). This implies an attempt to simplify and explain parts of the overall data through classification and categorization steps and linking one another so that a systematic descriptive series can be arranged and can provide meaning from the aspects studied.

Data analysis in qualitative research is more focused during the process in the field along with data collection. Herdiansyah (2010: 158) states, "data analysis is the middle stage of a series of stages in a study which has a very important function. The results of the resulting research must go through a data analysis process first so that they can be accounted for, a researcher must be able to perform data analysis appropriately and according to the prescribed procedure [7].

In quantitative research, data is obtained from various sources, using various data collection techniques (triangulation), and is carried out continuously until the data is saturated. With this continuous observation, the data variation is very high. Generally, the data obtained is quantitative data (although it does not reject quantitative data), so that the data analysis technique used is not yet clear. Therefore, they often experience difficulties in conducting analysis. As stated by Milles and Huberman (1984), that "the most serious and central in the us. Central difficult in the use of qualitative data is that methods of analysis aye not well formulate "(the most serious and difficult in qualitative data analysis is because the analytical method has not been well formulated) [8].

The data analysis technique in this study uses interactive analysis (Milles and Huberman, 1984), suggesting that activities in qualitative data analysis are carried out interactively and continue to completion, so that the data is saturated. Activities in data analysis, namely data reducation, display data, and conclusion drawing / verification [8].

Thus the interactive analysis process can be presented in the form of a diagram as stated by Miles and Huberman in Sugiyono (2012: 337) states that "Those who classify interactive analysis are 3 (three) types consisting of, reduction, data presentation, drawing conclusions and the following can see The details are presented in Figure 1 (one) below, namely, this Data Analysis Technique is carried out through the interactive analysis process referred to which is presented in the following schematic form [9]: 


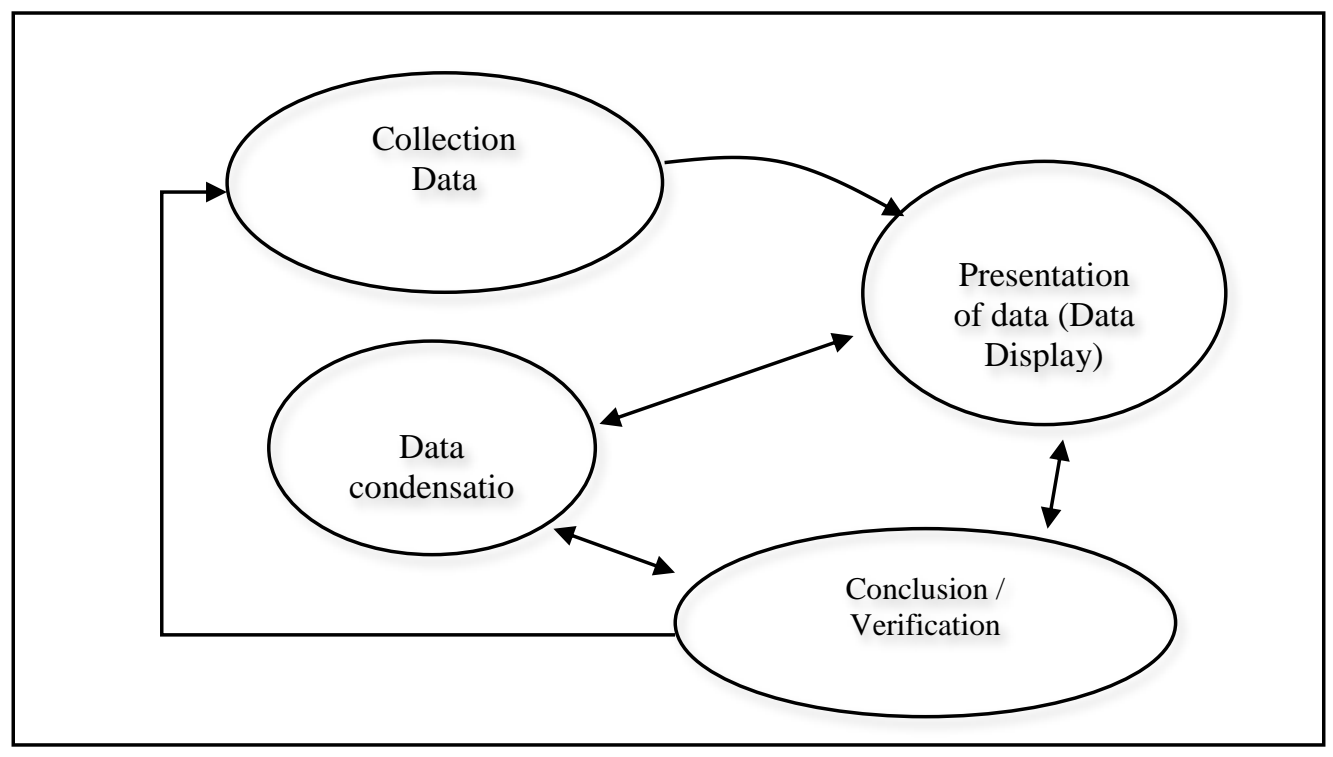

Figure 1: Miles and Huberman's Interactive Model Data Analysis

Source: Qualitative Data Analysis (Sugiyono 2014: 244)

Data collection, in interactive analysis is actually an action taken by researchers on any data that has been successfully collected in one stage and then analyzed through the act of analyzing the data, sorting it into units or giving certain codes, making syntheses, trying to find patterns and remain trying to be able to find something important "big", and "unique" so "interesting" and need to be studied scientifically, based on natural data so that at the final stage making decisions, systematically write them into a research report. However, data analysis in this study was also carried out by following the data collection process. In the analysis carried out by combining (interactively) the three main components are presented as follows:

\section{a) Data Condensation}

The amount of condensation data obtained in the field is quite large, so it needs to be recorded carefully and in detail. Reducing data means summarizing, choosing the main things, focusing on the things that are important, looking for themes and patterns and removing unnecessary. Thus data reduction as stated by Miles and Huberman in Sugiyono (2012: 337) states as follows: Condensation is a process of selection, focusing on simplification, abstracting, and rough data transformation that emerge from field notes "[9]. Through data reduction we can simplify qualitative data and transform it in various forms / ways, for example a rigorous selection is carried out, summarized or categorized into a clearer pattern.

The data that has been reduced will provide a clear picture and make it easier for researchers to carry out further data collection, and search for it if necessary. Data reduction can be assisted by electronic devices such as computers, by providing codes for certain aspects. With reduction, the researcher summarizes, retrieves important data, makes categorization, based on uppercase, lowercase letters and numbers, so that unnecessary data is discarded.

\section{b) Data Display}

After the data is reduced, the next step is to display the data. Data display in qualitative research can be done in the form of short descriptions, charts, relationships between categories, flowcharts and so on. Miles and Huberman in Sugiyono (2012: 337) state the following: "the most frequent form of display data for qualitative research data in the pas has been narrative tex" (which is most often used to present data in qualitative research with narrative text. )[9].

Apart from being in a narrative form, data displays can also be in the form of graphs, matrices, networks. Social phenomena are complex and dynamic, so that what is found when entering the field and after going on for a while in the field will experience data development. Researchers must always test what has been found when entering a field that is still developing or not. If after entering the field it turns out that the formulated analysis is always supported by data when it is collected in the field, then the analysis is proven and will develop into a grounded theory (developing a theory of interest in phenomena). If the patterns found have been supported by data during the study, then the pattern becomes a standard pattern that no longer changes. 


\section{c) Conclusion / Verification}

The third step is drawing conclusions and verification. The initial conclusions put forward are still provisional, and will change if no strong evidence is found to support them at the next data collection stage. However, if the conclusions have been supported by valid and consistent evidence when the researcher returns to the field to collect data, then the conclusions put forward are credible (trustworthy).

Conclusions in qualitative research may be able to answer the formulation of problems formulated from the start, but maybe not, because the problems and problem formulations in qualitative research are still temporary and will develop after the researcher is in the field. The conclusion in qualitative research that is expected is a new finding that had never existed before. Findings can be in the form of a description or description of an object that was previously unclear, so that after being examined it becomes clear.

The data collected is identified, processed and analyzed, then compiled into a form of scientific work using qualitative analysis, which is the procedure in a study by producing descriptive analytical data, namely what is stated in writing or orally, real behavior and something that is intact.

The three stages have been presented, data reduction, data modeling and drawing conclusions / verification as inter-links before, during and after data collection in parallel form, to form a common domain called "analysis".

In this study, the three types of analysis activities and data collection activities themselves form an interactive cycle process. The researcher steadily moves between these four models during data collection, then moves back and forth between reduction and continuation. As the matrix fills the page, conclusions, introductions are drawn, but these conclusions lead to the decision (for example) to add another column to the matrix to test the conclusions.

In this sense, qualitative data analysis is an ongoing, iterative initiative. The problems of model data reduction, and drawing or verifying conclusions are entered into the picture sequentially as the episodes of analysis follow each other. But the other two problems are always part of the foundation.

\section{RESEARCH RESULT DISCUSSION}

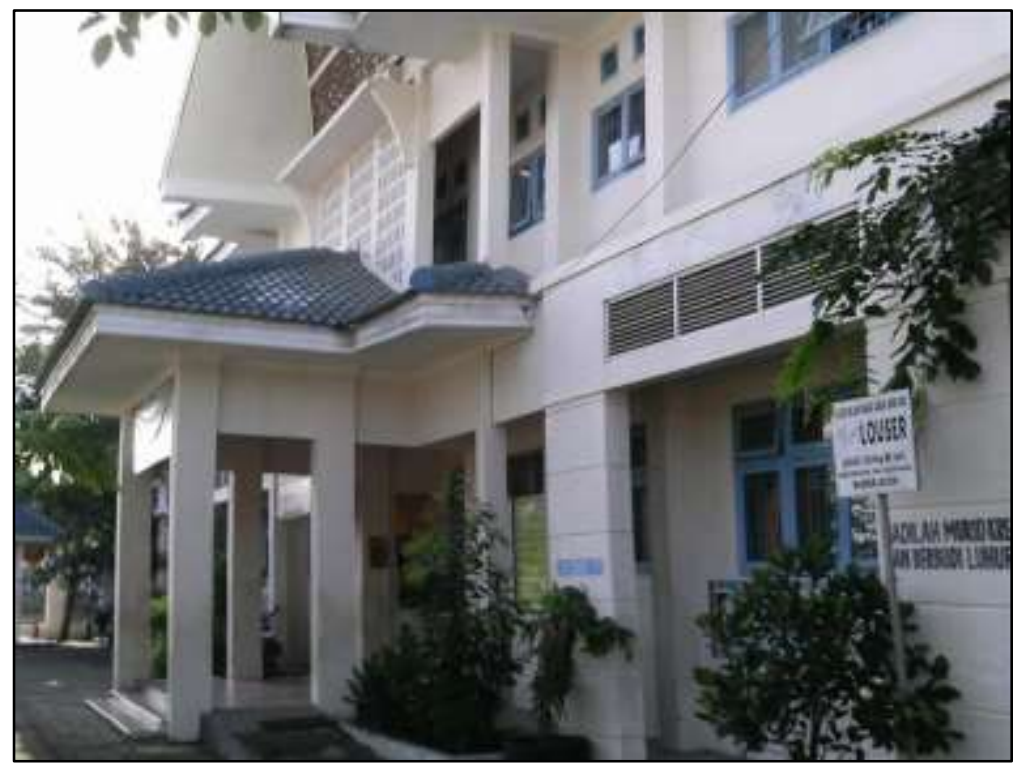

Figure 2. Profile of State 16 Elementary School of Banda Aceh City 
International Journal of Advances in Scientific Research and Engineering (ijasre), Vol 7 (4), April -2021

Table 1. Total number of teachers and employees: 28 people, with the following details

\begin{tabular}{|c|c|c|c|c|c|c|c|c|}
\hline \multirow[b]{2}{*}{ No. } & \multirow[b]{2}{*}{ Status / Position } & \multicolumn{7}{|c|}{ Last Education Level } \\
\hline & & $\begin{array}{c}<\text { Junior } \\
\text { High }\end{array}$ & $\begin{array}{c}\text { High } \\
\text { School }\end{array}$ & D2 & D3 & S1 & S2 & S3 \\
\hline 1. & Headmaster & & & & & 1 & & \\
\hline 2. & Civil servant teacher & & 2 & & & 14 & & \\
\hline 3. & Contract Teacher & & & & & 3 & & \\
\hline 4. & Honor Teacher & & & & & 3 & & \\
\hline 5. & Honor Librarian & & & & & 1 & & \\
\hline 6. & Operator & & & & & 1 & & \\
\hline 7. & School guard & 1 & & & & & & \\
\hline 8. & TU & & & & 1 & & & \\
\hline \multirow[t]{3}{*}{9.} & security & & 1 & & & & & \\
\hline & amount & 1 & 3 & & 1 & 23 & & \\
\hline & Total number & \multicolumn{7}{|c|}{28} \\
\hline
\end{tabular}

Table 2. The total number of Students is 383 people, with the following details

\begin{tabular}{|c|c|c|c|}
\hline \multirow{2}{*}{ No. } & \multirow{2}{*}{ Class } & \multicolumn{2}{|c|}{ Academic Year 2018 } \\
\cline { 3 - 4 } & & Amount & Rombel \\
\hline 1 & I & 64 & 2 \\
\hline 2 & II & 57 & 2 \\
\hline 3 & III & 71 & 2 \\
\hline 4 & IV & 60 & 2 \\
\hline 5 & V & 64 & 2 \\
\hline 6 & VI & 67 & 2 \\
\hline \multicolumn{2}{|c|}{ Amount } & $\mathbf{3 8 3}$ & $\mathbf{1 2}$ \\
\hline
\end{tabular}


International Journal of Advances in Scientific Research and Engineering (ijasre), Vol 7 (4), April -2021

Table 3. The following is a table of space, size, number, and building conditions:

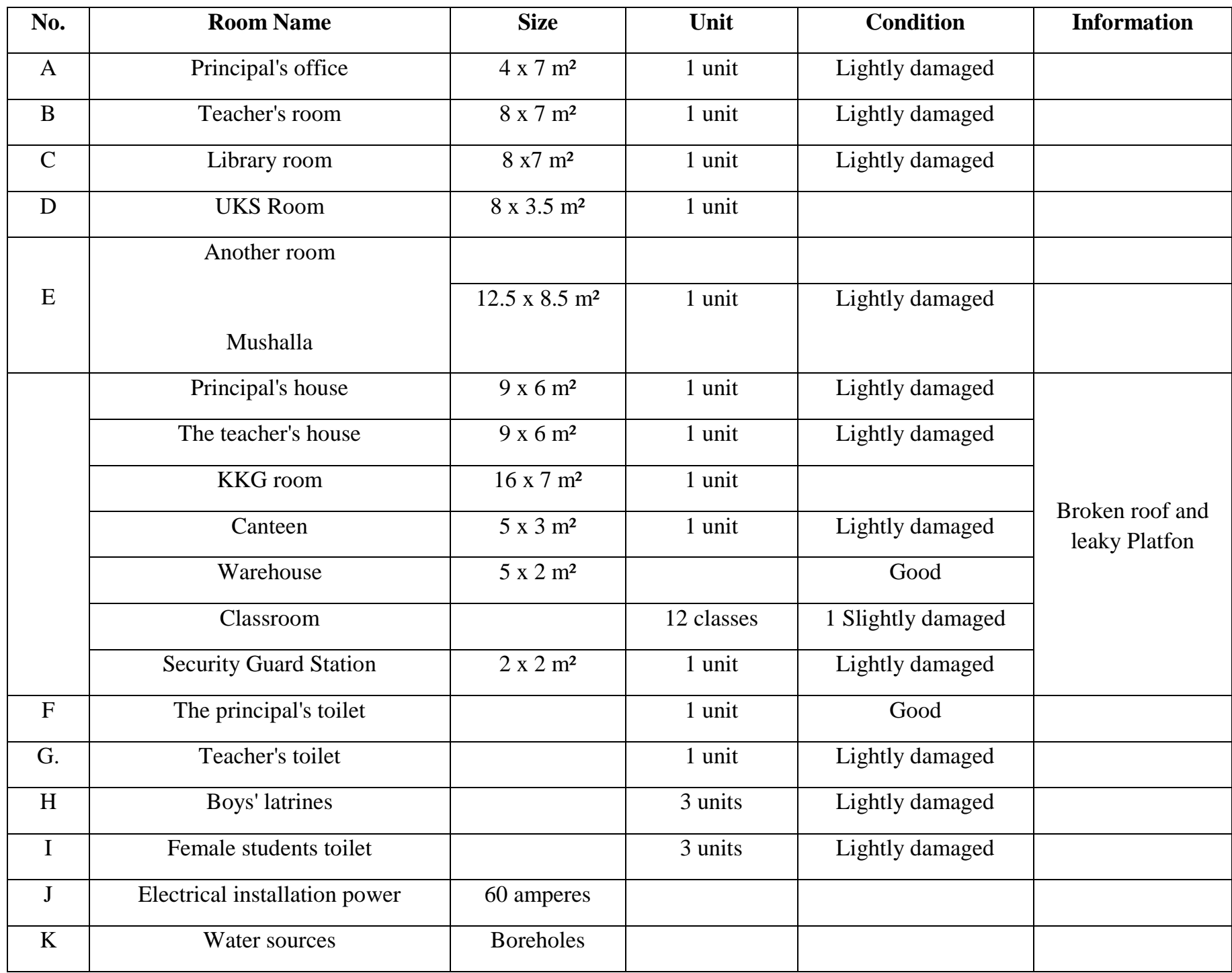

\section{DISCUSSION}

\subsection{Public Policy Implementation}

The discussion in this study uses the main theory of public policy implementation according to Edward III (1980), in addition to the theory of public policy implementation as the main theory, the discussion also uses several supporting theories, as illustrated in the framework of this study. Implementation is an action or also a form of real action in carrying out a well-designed plan, in other words, the implementation of this policy can only be done if there is already a pre-arranged planning. So, implementation is not just an act, but becomes an integral part of the planning that has been made. From this explanation it can be seen that implementation boils down to the mechanism of a system, a comprehensive system from upstream to downstream from planning to implementation and action and evaluation. The implementation of the implementation must be in accordance with the plans that have been made so that the results achieved are as expected. According to Edward III there are four things that must be considered in policy implementation, namely: Communication, Resources, Disposition and behavior (dispocition or attitides), and Bureaucratic structure (bureaucratic beaurocratic stapcure)

\section{1) Preparation for Implementation}

\section{Finding 1:}

In preparation for the implementation of the basic ideas of ecosystem policy, they are channeled and translated by leaders who care about education, Islamic education leaders, and leaders who care about education who are appointed by the National Education Ministry together with elements of school leadership. 


\section{Finding 2:}

Assistance and comparative studies were carried out jointly in Finland with the support of the regional government of the city and province of Aceh.

From these findings it can be formulated

\section{Minor proposition 1 :}

The world of education and culture is a very complex, challenging and noble world. Complex considering the spectrum is very broad, challenging because education determines the direction of a noble future to shape the character of the nation.

\section{2) Learning process}

\section{Finding 3:}

For the first time, teaching teachers received workshops and assistance on the implementation of the general curriculum combined with the learning process in the field or outside the classroom for three months.

\section{Finding 4:}

Awkwardness and stiffness in interactions outside the classroom are not used to it, so often it must be reminded by the companion in the learning process.

\section{Finding 5:}

In the teacher learning process, it is the tip of the successful application of an ecosystem-based curriculum and there is often less than optimal preparation.

From these findings it can be formulated

\section{Minor proposition 2 :}

Teaching methods and the development of teaching materials are tools that provide reinforcement of the teaching and learning process that underlies the concept of developing quality that is measured or used as a determining factor for excellence. Good quality is the manifestation of the educational authority in charge of the trust in teachers as stakeholders.

\section{3) Budget Support}

\section{Finding 6:}

There is full support for the education budget through the special autonomy fund and the regional budget (APBD) to innovate in changing general learning to the ecosystem paradigm.

\section{Finding 7:}

The amount of the budget to support the implementation of ecosystem-based education is not known about the real amount used because all needs through planning are the fulfillment of budget support and sources of compensation from various parties are solid support for community education.

From these findings it can be formulated

\section{Minor Proposition 3:}

The education budget and school expenditure are the heart that must always beat to meet the needs of schools, to show a healthy school.

\section{4) Human Resources}

\section{Finding 8:}

Teacher competence and professionalism are cultivated through formal teacher certification channels that create selfportfolios, which can describe a collection of certificates and training programs, workshops on education that they have participated in as a teacher.

\section{Finding 9:}

Many teachers are taking advanced studies that are still possible to take or take part in seminars, training and workshops to develop teaching materials and teachers can make portfolios for formic and diagnostic assessment materials in improving teacher skills. 
From the findings above, it can be formulated

\section{Minor Proposition 4:}

School management must be serious in improving the abilities and capabilities of teachers because teachers can create relatively stable quality improvements in schools, new possibilities for educators to reflect on their teaching methods, looking for and testing new ideas, methods, materials, a new approach applied in schools .

5) Development Strategy

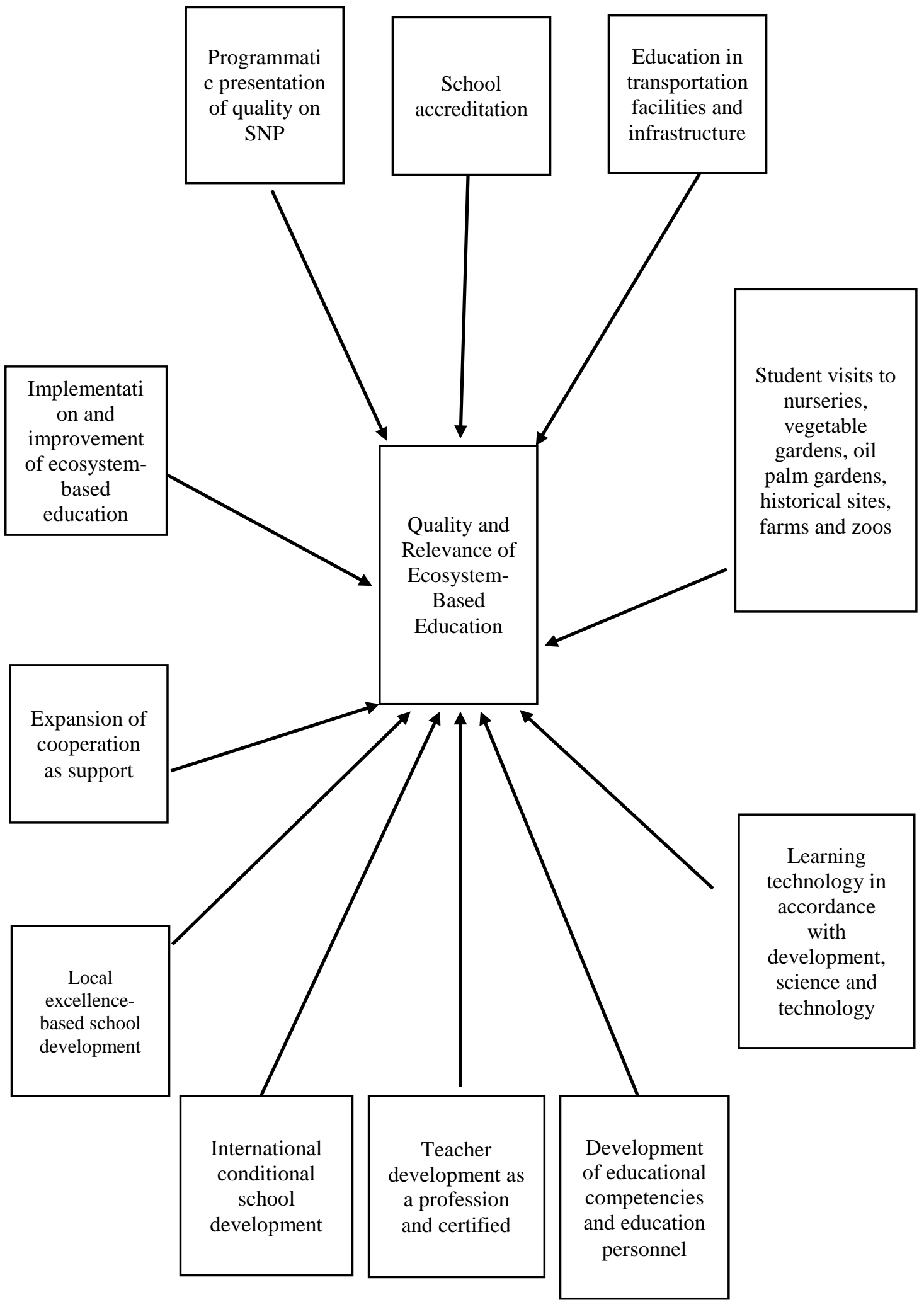

Figure 3. Development Strategy 
Finding 10:

The existence of KKG, learning houses, and home cinema is an adaptation strategy in the learning process during a pandemic, which conditions do not allow face-to-face and field visits.

\section{Finding 11:}

Capturing opportunities during a pandemic for the learning process of parents facilitating the purchase of cellphones and also helping to access learning process applications which generally have separate complaints because they take up parents' time to accompany the learning process of the online model.

From these findings it can be formulated

\section{Minor Proposition 5:}

The development strategy in the learning process that has been constructed through the advantages of technological media requires the domination of parents and other stakeholders and policy implementers to always be adaptive to the development of online situations and conditions.

\subsection{Encouraging and Obstacle Elements in the Implementation of Education at STATE 16 ELEMENTARY SCHOOL} Banda Aceh City

1) Driving Elements Internally and Externally

\section{Finding 12:}

Heridity, personality, family, and teachers or educators are dominant indicators in shaping students as students in this school environment.

\section{Finding 13:}

social environment as a determinant of one's morals and the formation of one's best attitudes in the sphere of education.

\section{2) Inhibiting Elements Internally and Externally}

\section{Finding 14:}

The development of technological media can be positive when receiving parental assistance, but there are many negatives if children are allowed to manage themselves in involvement with the use of technological media tools.

From these findings, it can be formulated

\section{Minor Proposition 6:}

The character building of the educational learning process is very much determined by the development of technology media, the involvement of parents, as well as the support of a conducive environment in the lives of students at school and in the family as well as in the community.

From minor propositions 1-6 can be formulated

\section{Major proposition :}

The learning process is through the implementation of ecosystem-based elementary school education which is formed through the involvement and support of school stakeholders and the presence of local governments so that personality, character, environmental awareness are created, in adapting to realize ecosystem-based schools.

\section{CONCLUSIONS AND IMPLICATIONS}

\subsection{Conclusion}

Based on data from research results, analysis and discussion in the previous chapter on the implementation of ecosystem-based education policy at STATE 16 ELEMENTARY SCHOOL Banda Aceh City based on the Kadiknas letter No 420 / A.3 / 5200 dated 10 December 2019 concerning the establishment of ecosystem-based school management, it can be taken the following conclusions: 
1) Implementation of ecosystem-based school education policies.

Several elements have been described through:

a) Preparation for implementation. The implementation preparation that supports a communication from Edward III's theory has obtained the following proposition 1: The world of education and culture is a very complex, challenging and noble world. Complex considering the spectrum is very broad, challenging because education determines the direction of a noble future to shape the character of the nation.

b) Learning process. In the learning process which is also part of communication, proposition 2 can be formulated as follows: Teaching methods and teaching material development is a tool that provides reinforcement to the teaching and learning process that underlies the concept of developing quality that is measured or used as a determining factor for excellence. Good quality is the manifestation of the educational authority in charge of the trust in teachers as stakeholders.

c) Budget and human resource support. Budget support and human resources are part of the resources that can be formulated in propositions 3 and 4 as follows: The education budget and school expenditure are the heart that must always beat to meet the needs of schools, to show a healthy school. School management must be serious in improving the abilities and capabilities of teachers because teachers can create relatively stable quality improvements in schools, new possibilities for educators to reflect on their teaching methods, looking for and testing new ideas, methods, materials, a new approach applied in schools .

d) Development strategy. Part of the bureaucratic disposition and structure that can be formulated through proposition 5 as follows: Development strategies in the learning process that have been constructed through technological media excellence require the domination of parents and other stakeholders and policy implementers to always be adaptive to developments in online situations and conditions.

2) Inhibiting and supporting elements from the results of this study.Inhibiting and supporting elements can be formulated as follows: Proposition 6 can be formulated as follows: The character formation of the educational learning process is largely determined by the development of technology media, parental involvement as well as support for a conducive environment in the lives of students at school and in the family as well Public.

\subsection{Theoretical Implications}

The implication of research theory is a direct consequence of the findings of the research conducted. In this research generally develops and supports existing theories, namely the policy implementation process, the policy implementation process based on George's policy implementation model. C. Edward III.

The policy implementation model with the takedown perspective developed by George Edward III (in Kridawati, 2011) named his public policy implementation model with the impact on implementation index.In this theoretical approach, there are four indicators that influence the successful implementation of a policy, namely:

1) Communication.

The first indicator that affects the successful implementation of a policy is communication. According to him, communication really determines the success of achieving the objectives of the implementation of public policies, effective implementation occurs when the decision makers already know what they are going to do. Knowledge of what they will do, can work if communication goes well so that every policy decision and implementation regulations must be transmitted (communicated) to all appropriate personnel. In addition, the policies communicated must be precise, accurate and consistent. Communication (transmission of information) is needed so that decision makers and policy implementers will be more consistent in implementing every policy that will be applied in society,

2) Resource

The second indicator that affects the successful implementation of a policy is resources. Resources are another important thing in implementing a policy. The resource sub indicator consists of several elements: Staff, Information, Authority, and Facilities.

3) Disposition

The third indicator that affects the success of policy implementation is disposition. The important things that need to be considered in the disposition indicators are:

a) The appointment of the bureaucrat's disposition or the attitude of the executor will cause real obstacles to policy implementation if the existing personnel do not carry out the policies desired by the officials above them. 
b) Incentive. Incentives are one of the techniques suggested to overcome the problem of implementers' tendency to manipulate incentives. Therefore, people generally act according to their own interests so manipulating incentives by policy makers influences the actions of policy implementers. By adding certain benefits or costs which may be a driving factor that makes policy implementers carry out orders properly.

4) Bureaucratic Structure

The bureaucratic structure is an indicator that influences the success in implementing public policy even though the resources to implement a policy are available or policy implementers know what should be done and have the desire to implement a policy.

From this description it can be concluded as follows:

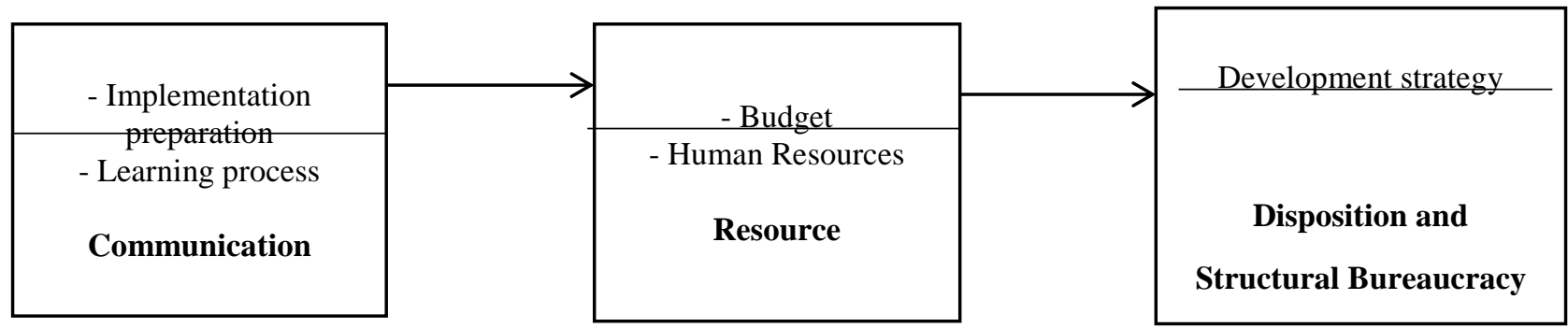

Figure 4. Public Policy Implementation

George. Edward III and Combined with Research Results

\subsection{Practical Implications}

Based on the research results as stated in the previous chapter, practical implications can be formulated as follows:

1) The research findings show that the process of implementing this ecosystem-based education is still running for about 3 years and after the stipulation of the policy is still taking place for 3 years, there are many things that need to be refined again to get to a real implementation process in accordance with the vision and mission of the school which is also desired by policy makers. especially for local governments to always support some needs and ideas for improvement in the implementation of the learning process both inside the classroom and outside the classroom and school.

2) The results of the research findings show that the involvement of stakeholders and committees as well as related parties who have supported their CSR are also asked to participate in the continuation of support in improving the implementation of ecosystem-based elementary school policies.

3) The people of Banda Aceh City and Aceh Province should always consider and learn about this school so that they are expected to contribute their ideas and thoughts so that this school can accommodate new students according to their capacity and competence.

\section{REFERENCES}

1. Christopher Pollit and Geert Bouckaert. 2000. Public Management reform: A Comparative Analysis. London: Oxford University Press.

2. Sadhana, Kridawati. 2011. Reality of Public Policy. Pustaka State University of Malang (University Press), Malang.

3. Koesoema, Doni. 2010. Character Education; Strategy for Educating Children in a Global Age. Jakarta: Grasindo.

4. Siswoyo, Dwi et al. 2007, Science Education, Yogyakarta: UNY Press.

5. Admodiwirio, Soebagio. 2000. Indonesian Education Management. Jakarta: Ardadizya Jaya.

6. Daryanto. 1997. Educational Evaluation. Jakarta: Rineka Cipta. Ministry of National Education.

7. Herdiansyah, Haris. 2010. Qualitative Research Methods for Social Sciences. Jakarta: Salemba Humanika.

8. Miles, M.B \& Huberman A.M. 1984. Qualitative Data Analysis. Translation by Tjetjep Rohendi Rohidi. 1992. Jakarta: University of Indonesia Publishers.

9. Sugiyono. 2012. Quantitative Qualitative Research Methods and R\&B. Bandung: Alfabeta. 